\title{
PENGARUH PELATIHAN TERHADAP PENGETAHUAN TENTANG GIZI BURUK DAN INTER-PROFESSIONAL COLLABORATION PETUGAS PUSKESMAS
}

\author{
Risnah $^{1}$, Rosmah $^{2}$, Mustamin $^{3}$, Imam Sofingi ${ }^{4}$ \\ ${ }^{1}$ Mahasiswa Program Doktor Fakultas Kesehatan Masyarakat UNHAS Makassar \& Dosen \\ Keperawatan Fakultas Kedokteran dan Ilmu Kesehatan UIN Alauddin Makassar \\ 2Puskesmas Togo-togo Kabupaten Jeneponto \\ ${ }^{3}$ Dinas Kesehatan Kabupaten Jeneponto \\ ${ }^{4}$ Puskesmas Binamu Kota Kabupaten Jeneponto \\ *risnah_ina@yahoo.com
}

DOI : 10.24252/jkesehatan.v11i1.5030

\begin{abstract}
ABSTRAK
Permasalahan kesehatan yang sangat kompleks memerlukan penanganan yang melibatkan seluruh profesi kesehatan. Status gizi anak menjadi salah satu hal penting untuk mempersiapkan generasi berkualitas. Pendidikan kesehatan dalam bentuk pelatihan diharapkan mampu mengubah kompetensi kolaborasi lintas profesi petugas kesehatan. Dengan Tujuan penelitian adalah mengetahui pengaruh pelatihan pada petugas kesehatan terhadap pengetahuan tentang gizi buruk dan kolaborasi lintas profesi. Penelitian ini menggunakan pendekatan Mix-Methode dengan teknik triangulasi menggunakan kuesioner untuk tahapan kualitatif dengan melakukan analisis kontent dan pada tahapan kuantitatif menggunakan metode Rancangan penelitian "Pra Experiment" dengan desain penelitian menggunakan "one group pre and post test design". Uji normalitas menggunakan Shapiro-Wilk. Analisa statistik menggunakan Wilcoxon test dan paired $T$ test. Hasil penelitian menunjukkan bahwa analysis content menginformasikan bahwa pelatihan telah berlangsung dengan baik dan mampu meningkatkan pengetahuan peserta. Hasil uji statistik menunjukkan bahwa pengetahuan tentang gizi sebelum pelatihan memiliki rerata 4.50 dan setelah pelatihan memiliki rerata 4.467. Hal ini tidak menunjukkan peningkatan rerata. Hasil uji statistik yakni uji $\mathrm{T}$ tes menunjukkan nilai $\mathrm{p}=0.586(\mathrm{p}>0.05)$ yang bermakna bahwa tidak ada perbedaan rerata pengetahuan tentang gizi sebelum dengan setelah perlakuan. Sedangkan untuk pengetahuan tentang kolaborasi sebelum pelatihan memiliki rerata 8.75 dan setelah pelatihan memiliki rerata 10.67. Hal ini menunjukkan adanya peningkatan rerata. Hasil uji statistik menunjukkan nilai $\mathrm{p}=0.008$ $(\mathrm{p}<0.05)$ yang menunjukkan ada perbedaan rerata pengetahuan tentang kolaborasi sebelum dengan setelah perlakuan pada kelompok uji coba modul. Sehingga pelatihan kolaborasi lintas profesi pada penanganan gizi buruk berpengaruh terhadap perubahan pengethauan petugas kesehatan.Terdapat perbedaaan perubahan pengetahuan gizi buruk dan kolaborasi lintas profesi sebelum dan setelah pelatihan.
\end{abstract}

Kata kunci : Pelatihan, Gizi buruk, Inter-professional Collaboration 


\begin{abstract}
Very complex health problems require treatment involving all health professionals. The nutritional status of children is one of the important things to prepare a quality generation. Health education in the form of training is expected to change the competence of collaboration across healthcare professionals. The aim of the study was to determine the effect of training on health workers on knowledge about malnutrition and collaboration across professions. This study uses a Mix-Method approach with triangulation techniques using a questionnaire for qualitative stages by conducting a content analysis and on a quantitative stage using the research design method "Pre Experiment" with a research design using "one group pre and post-test design". Test for normality using Shapiro -Wilk. Statistical analysis using the Wilcoxon test and paired T-test. The Results showing are analysis content informs that the training has been going well and is able to increase participants' knowledge. Statistical test results show that nutrition knowledge before training has a mean of 4.50 and after training has a mean of 4,467. This does not show an increase in average. The results of the statistical test, namely the test T-test showed $p$ value $=0.586(p>0.05)$ which means that there is no difference in mean knowledge about nutrition before and after treatment. As for knowledge about collaboration before training has a mean of 8.75 and after training has a mean of 10.67. This shows an increase in average. Statistical test results show $p$-value $=$ $0.008(p<0.05)$ which shows that there is a difference in mean knowledge about collaboration before the treatment in the module testing group. So, Cross-professional collaboration training in handling malnutrition affects changes in health worker knowledge. There are differences in changes in knowledge of malnutrition and collaboration across professions before and after training.
\end{abstract}

Keywords: Training, Poor Nutrition, Inter-professional Collaboration

\title{
PENDAHULUAN
}

Kolaborasi adalah hubungan saling menguntungkan dan terdefinisi dengan baik yang disepakati oleh dua atau lebih organisasi untuk mencapai tujuan bersama (Posthumus A dkk, 2013). Hal ini merupakan istilah yang umum digunakan dalam penelitian, praktek klinis, dan pendidikan profesi kesehatan, hingga terjadi kolaborasi di hampir setiap aspek kesehatan (Green BN dan Johnson CD, 2015). Permasalahan pada bidang kesehatan yang sangat kompleks memerlukan penyelesaian secara bersama dengan melibatkan seluruh profesi kesehatan (Indonesia KKR, 2015). Kerjasama dilakukan dengan upaya preventif dan promotif tanpa mengabaikan pendekatan kuratif dan rehabilitative (Sumarni S, 2015).

Kolaborasi inter-professional memiliki efek positif pada kepuasan pasien, mengurangi ketidakpastian, dan meningkatkan manajemen nyeri (Rodriguez dkk, 2008). Praktek kolaboratif inter-professional sangat penting untuk perbaikan hasil pelayanan kesehatan pada pasien / klien dan keluarga (Bainbridge dkk, 2010) World Health Organization (WHO) tahun 2010 menyatakan bahwa sekarang ini banyak sistem kesehatan di negara-negara di dunia yang mengimplementasikan pelayanan kesehatan terfragmentasi yang pada akhirnya tidak mampu menyelesaikan masalah kesehatan di negara itu sendiri. 
Salah satu masalah kesehatan yang kompleks yakni status gizi buruk. Permasalahan yang ditimbulkan oleh status gizi buruk adalah kondisi yang tidak maksimal pada pertumbuhan dan perkembangan seorang anak. Sehingga upaya lain untuk mengatasi masalah gizi diperlukan aksi lintas sektoral (Unicef, 2012). Secara global, $45 \%$ kematian anak dibawah usia 5 tahun diakibatkan oleh berbagai kondisi kekurangan gizi (Black dkk, 2013). Status gizi anak dapat diketahui dengan menggunakan pedoman penentuan status gizi yang tepat (Alfridsyah dkk, 2013). Secara ilmiah ada hubungan antara mikronutrien dan pertumbuhan anak tetapi hal ini masih diperdebatkan (Syam dkk, 2016).

Pertumbuhan maksimal diderita sekitar 8 juta anak Indonesia, atau satu dari tiga anak Indonesia (Dasar RK, 2013). Pada tahun 2007 sampai 2011, proporsi penduduk miskin di Indonesia mengalami penurunan sebesar 16,6 - 12,5\%, tetapi masalah gizi tidak menunjukkan penurunan secara signifikan (Unicef, 2012). Banyak factor yang mempengaruhi status gizi anak salah satunya adalah pola pemberian ASI dan MP-ASI. (Susanty dkk, 2012) walaupun belum ditemukan korelasi antara kadar kalsium dalam ASI, PASI dan MPASI dalam intake bayi dengan panjang badan bayi usia $6-12$ bulan (Febria dkk, 2018). Pola asuh juga berhubungan dengan kejadian stunting pada anak usia 6 - 23 bulan di Makassar (Renyoet dkk, 2012). Masih tingginya kejadian anemia defisiensi zat besi pada ibu hamil akan berfefek pada kondisi janin (Amiruddin, 2007).

Gambaran tentang status gizi balita berdasarkan indeks BB/U di atas target MDGs $(15,5 \%)$ menurut kota / kabupaten diperoleh informasi bahwa ada lima kabupaten dengan presentase tinggi gabungan gizi buruk dan gizi kurang yaitu Pangkep 31,7 \%, Maros 31 \%, Takalar 29,6 \%, Makassar 29,6 \% dan Jeneponto 28,4 \% (Sul-Sel DKp, 2015). Kabupaten Jeneponto memiliki status gizi buruk dan gizi kurang kategori masalah sedang sebesar $26,4 \%$ sedangkan kasus gizi buruk sebanyak 7 orang $(0,04 \%)$ (Departemen Kesehatan Jeneponto, 2015)

Berdasarkan latar belakang di atas, maka kerjasama lintas sektor menjadi salah satu kunci penting bagi suksesnya pembangunan kesehatan termasuk penanggulangan masalah gizi pada anak sehingga tulisan ini bertujuan untuk mengetahui pengaruh pelatihan terhadap pengetahuan tentang kolaborasi lintas profesi kesehatan pada penanganan kasus gizi buruk di Kabupaten Jeneponto.

\section{METODOLOGI PENELITIAN}

Jenis Penelitian yang digunakan adalah deskriptif menggunakan mix methode (kualitatif dan kuantitatif). Dimaksudkan untuk mengetahui pengaruh pelatihan terhadap pengetahuan tentang kolaborasi lintas profesi kesehatan pada penanganan kasus gizi buruk. Penelitian ini dilaksanakan di Puskesmas Binamu Kota Kabupaten Jeneponto pada tanggal 5 - 6 Desember 2017. Populasi dalam penelitian ini adalah semua petugas kesehatan yang bertugas di Puskesmas Binamu Kota Kabupaten Jeneponto. Responden sebanyak 12 orang yang didapatkan dengan teknik stratified 
random sampling dan itu juga yang digunakan sebagai Informan. Pengumpulan data dilakukan dengan dua cara yaitu data primer melalui pengisian kuesioner, wawancara mendalam dengan informan dan observasi. Data sekunder berupa profil Puskesmas, jumlah petugas kesehatan dan data-data lain yang diperlukan. Data yang telah dikumpulkan kemudian diuji normalitas data dan disajikan dalam bentuk tabel distribusi frekuensi. Selanjutnya karena data pengetahuan gizi buruk terdistribusi tidak normal maka dilakukan uji Wilcoxon dan pengetahuan tentang kolaborasi lintas profesi terdistribusi normal maka dilakukan uji t berpasangan. Untuk data kualitatif, dianalisis menggunakan analisis conten dan matriks pernyataan informan dilakukan perbandingan dengan data kuantitatif yang telah diolah.

\section{HASIL DAN PEMBAHASAN}

\section{A. Karakteristik Responden}

Tabel 11. Analisis karakteristik responden pada Puskesmas Binamu Kota di Kab. Jeneponto tahun 2017

$\begin{array}{lll}\text { Karakteristik } & \text { N } & \%\end{array}$

Jenis Kelamin

Laki-laki

325

Perempuan

9275

Tingkat Pendidikan

Strata I

$5 \quad 42$

Diploma

\section{Usia}

$20-30$ tahun $\quad 5 \quad 41,2$

$31-40$ tahun $\quad 5 \quad 41,2$

$\begin{array}{lll}41-50 \text { tahun } & 2 & 16,6\end{array}$

\section{Profesi}

$\begin{array}{lll}\text { Dokter } & 2 & 16,6\end{array}$

$\begin{array}{lll}\text { Perawat } & 2 & 16,6\end{array}$

$\begin{array}{lll}\text { Bidan } & 3 & 25\end{array}$

$\begin{array}{lll}\text { Nutrisionis } & 2 & 16,6\end{array}$

$\begin{array}{lll}\text { Sanitarian } & 2 & 16,6\end{array}$

$\begin{array}{llr}\text { Promosi kesehatan } & 1 & 8,3\end{array}$

$\begin{array}{lll}\text { Total } & 12 & 100\end{array}$


Tabel 1.1 memperlihatkan bahwa mayoritas informan berjenis kelamin perempuan, yaitu sebanyak 9 orang (75 \%) dan laki-laki hanya 3 orang (25\%). Tingkat pendidikan informan yang menyelesaikan pada tingkat strata 1 sebanyak 5 orang $(42 \%)$ dan yang menyelesaikan pada tingkat Diploma baik itu Diploma III maupun Diploma IV sebanyak 7 orang (58\%). Kelompok usia informan yakni usia 20 - 30 tahun dan $31-40$ tahun masing-masing sebanyak 5 orang $(41,2 \%)$ dan untuk kelompok usia $41-50$ tahun sebanyak 2 orang $(16,6 \%)$. Selain itu profesi yang dimiliki informan bervariasi yakni; dokter 2 orang $(16,6 \%)$, perawat 2 orang $(16,6 \%)$, Bidan 3 orang $(25 \%)$, nutrionis 2 orang $(16,6 \%)$, sanitarian 2 orang $(16,6 \%)$ dan tenaga promosi kesehatan 1 orang $(8,3$ $\%)$.

\section{B. Pengetahuan Responden}

Pada penelitian ini mengukur pengetahuan subyek maka peneliti memberikan pretest sebelum kegiatan pelatihan dan di berikan modul saat kegiatan pelatihan berlangsung. Setelah kegiatan pelatihan maka dilakukan kembali post-test.

Tabel 1 2. Perubahan Pengetahuan responden pre dan post pelatihan di Kabupaten Jeneponto tahun 2017

\begin{tabular}{lccccc}
\hline \multirow{2}{*}{ Pengetahuan } & \multicolumn{2}{c}{ Pre } & \multicolumn{2}{c}{ Post } & \multirow{2}{*}{ Nilai $p$} \\
\cline { 2 - 5 } & Mean & SD & Mean & SD & \\
\hline Gizi buruk & 4.50 & .674 & 4.67 & .492 & $0.586^{*}$ \\
\hline Kolaborasi & 8.75 & .965 & 10.67 & 1.670 & $0.008^{* *}$ \\
\hline
\end{tabular}

Sumber : Data Primer

Keterangan : Uji Wilcoxon dan Uji T Test

Dari Tabel 1.2 di atas menunjukkan bahwa untuk pengetahuan tentang gizi sebelum pelatihan memiliki rerata 4.50 dan setelah pelatihan memiliki rerata 4.467 . Hal ini tidak menunjukkan peningkatan rerata. Hasil uji statistik yakni uji $\mathrm{T}$ tes menunjukkan nilai $\mathrm{p}=0.586(\mathrm{p}>0.05)$ yang bermakna bahwa tidak ada perbedaan rerata pengetahuan tentang gizi sebelum dengan setelah perlakuan.

Sedangkan untuk pengetahuan tentang kolaborasi sebelum pelatihan memiliki rerata 8.75 dan setelah pelatihan memiliki rerata 10.67. Hal ini menunjukkan adanya peningkatan rerata. Hasil uji statistik menunjukkan nilai $\mathrm{p}=0.008(\mathrm{p}<0.05)$ yang menunjukkan ada perbedaan rerata pengetahuan tentang kolaborasi sebelum dengan setelah perlakuan pada kelompok uji coba modul. 
Dalam mendukung penelitian ini secara kualitatif, maka dilakukan indepth interview pasca pelatihan. Secara umum diperoleh informasi baru dan terjadi perubahan pengetahuan peserta tentang gizi buruk dan kolaborasi setelah mengikuti pelatihan sebagaimana sesuai kutipan berikut :

1. “...Bagus, penjelasannya sangat terarah. Mendapat pelajaran yang sangat berarti. (SR.Perawat)

2. “...Terima kasih, sudah melakukan pelatihan ini di tempat kami sehingga kami dapat ilmu baru (SA.Bidan)

3. "...... Saya sangat berterima kasih ada ibu untuk memberikan pelatihan ini karena menambah ilmu bagi saya (NI. Ahli gizi)

4. "....... Saya sangat berterima kasih dengan kehadiran yang telah menambah pengetahuan kami tentang pentingnya kolaborasi dalam semua kegiatan utamanya program kami (EE.Sanitarian)"

Evaluasi tentang proses pelatihan yang telah berlangsung secara lancar dan ternilai bagus oleh peserta. Sebagaimana beberapa kutipan pernyataan sebagai berikut;

1. “...Tema pelatihan sangat kreatif, inovasi dan bermanfaat. Penyajian materi dikemas sangat menarik sehingga tidak membosankan. Servis mantap. Narasumber ramah dan selalu memberi kesempatan peserta untuk memberi umpan balik."(AD, Dokter)

2. "....Pembawaan materinya sangat bagus dan mudah dipahami. Berkolaborasi dengan pesertanya dengan mudah." (KS, Tenaga Promkes)

\section{PEMBAHASAN}

Dalam penelitian ini, diperoleh bahwa setelah kegiatan uji coba modul maka pengetahuan tentang gizi buruk setelah dilakukan uji statistik yakni uji Wilcoxon memperoleh nilai 0,586 bermakna bahwa tidak ada perbedaan rerata pengetahuan tentang gizi sebelum dengan setelah perlakuan namun pengetahuan tentang kolaborasi lintas profesi setelah dilakukan uji $\mathrm{T}$ test memperoleh nilai 0,008 menunjukkan ada perbedaan rerata pengetahuan tentang kolaborasi sebelum dengan setelah perlakuan pada kelompok uji coba modul.

Pemahaman yang baik tentang kolaborasi lintas profesi telah dimiliki oleh petugas kesehatan. Kolaborasi adalah istilah yang umum digunakan dalam penelitian, praktek klinis, dan pendidikan profesi kesehatan (Green, 2015). Bekerja dengan cara yang interprofessional bukanlah konsep baru. Pada literatur profesional, terutama dalam ilmu kesehatan jelas bahwa sangat banyak manfaat dan tantangan untuk mengintegrasikan tenaga kerja untuk belajar dan menghargai budaya profesi lainnya. Keterampilan ini dapat dialihkan untuk banyak daerah di mana orang bekerja sama dengan profesi lain untuk mencapai tujuan bersama (BORST J, 2011).

Upaya meningkatkan kolaborasi di pelayanan kesehatan dapat dilakukan dengan berbagai cara dalam pendidikan kesehatan. Salah satu strategi yang dipergunakan 
beruapa kegiatan pelatihan. Banyak pelatihan yang telah dilaksanakan dan berpengaruh pada pengetahuan dari peserta kegiatan tersebut. Diantaranya adalah program pelatihan pemeriksaan payudara sendiri yang memberikan perubahan pengetahuan pesertanya setelah mengikuti pelatihan tersebut (Seif dan Aziz, 2000).

Walaupun ada juga pelatihan yang tidak mampu mengubah pengetahuan peserta pelatihan setelah dilakukan uji pre dan post intervensi. (Ellis dkk, 2007) Namun dipahami bahwa Pengetahuan, keterampilan dan motivasi mempunyai hubungan dengan kinerja bidan (Palutturi, 2007). Karena factor social dan psikologis berhubungan dengan pelayanan kesehatan (Saleh, Amir dan Palutturi, 2012). Sehingga upaya penanganan kasus gizi buruk memerlukan kemampuan kolaborasi lintas profesi kesehatan dalam sebuah sistem pelayanan kesehatan.

Selain itu keberadaan kader juga perlu diperhatikan dalam pelayanan kesehatan karena keberadaan kader yang mempunyai pengetahuan dan keterampilan untuk menyampaikan informasi dan motivasi kepada wanita prakonsepsi dalam mendapatkan akses pelayanan kesehatan (Paridah dan Thaha, 2014). Pendidikan kesehatan merupakan salah satu upaya dalam penambahan pengetahuan dan kemampuan seseorang dengan tujuan untuk mengingat fakta atau kondisi nyata. Dengan cara memberi dorongan terhadap pengarahan diri serta aktif dalam memberikan informasi atau ide baru (Suliha, 2002).

Konsep pendidikan kesehatan adalah konsep pendidikan yang diaplikasikan pada bidang kesehatan. Konsep dasar pendidikan adalah suatu proses belajar yang berarti dalam pendidikan itu terjadi proses pertumbuhan, perkembangan, atau perubahan kearah yang lebih dewasa, lebih baik, lebih matang pada diri individu, kelompok / masyarakat. Konsep pendidikan kesehatan itu juga proses belajar pada individu, kelompok atau masyarakat dari tidak tahu tentang nilai-nilai kesehatan menjadi tahu, dari tidak mampu mengatasi masalah kesehatan menjadi mampu mengatasi masalah kesehatan.

Pendidikan kesehatan adalah penambahan pengetahuan dan kemampuan seseorang melalui teknik praktik belajar atau instruksi, dengan tujuan untuk mengingat fakta atau kondisi nyata, dengan cara memberi dorongan terhadap pengarahan diri (self direction), aktif memberikan informasi atau ide baru (Suliha, 2002). Pendidikan kesehatan adalah proses perubahan perilaku yang dinamis bukan proses pemindahan materi dari seseorang ke orang lain dan bukan pula seperangkat prosedur.

Hal itu dapat dilihat dari definisi yang dikemukakan yaitu pendidikan kesehatan adalah suatu proses perubahan pada diri seseorang yang dihubungkan dengan pencapaian tujuan kesehatan individu, dan masyarakat. Dari definisi tersebut menunjukkan bahwa pendidikan kesehatan merupakan suatu proses perubahan perilaku yang dinamis dengan tujuan mengubah atau memengaruhi perilaku manusia yang meliputi komponen pengetahuan, sikap, ataupun praktik yang berhubungan 
dengan tujuan hidup sehat baik secara individu, kelompok maupun masyarakat, serta merupakan komponen dari program kesehatan (Notoatmodjo, 2007).

Sesuatu yang dipelajari akan membentuk pengetahuan, seringkali pengetahuan tersebut terlupakan. Ada beberapa sebab seseorang yang telah memperoleh pengalaman tetapi sulit diingat, Seseorang cenderung lupa karena tergantung pada sesuatu yang diamati, situasi dan proses pengamatan berlangsung serta waktu (Purwanto, 1990). David Kolb yang dikutip Depkes RI menyatakan bahwa pengetahuan sebagai hasil dari proses belajar sangat dipengaruhi oleh waktu sejak memperoleh pemaparan (Departemen Kesehatan R.I, 2001).

Ada beberapa faktor yang memengaruhi pengetahuan seseorang yakni

1) Tingkat pendidikan, Sebagaimana kita pahami bahwa semakin tinggi tingkat pendidikan seseorang, maka yang bersangkutan akan lebih mudah dalam proses menerima hal-hal baru sehingga pada akhirnya akan lebih mudah pula menyelesaikan persoalan terkait dengan hal-hal baru tersebut.

2) Informasi, Bila seseorang mempunyai sumber informasi yang lebih baik, akurat dan banyak maka akan memberikan pengetahuan yang jelas berdasarkan pada sumber informasi tersebut.

3) Budaya dapat dipahami memberikan efek yang sangat mempengaruhi tingkat pengetahuan seseorang, karena berbagai informasi baru yang masuk akan disaring oleh individu untuk memilah kira-kira informasi tersebut sesuai atau tidak dengan kebudayaan yang telah ada dan agama yang dianut masyarakat.

4) Pengalaman, sangat berkaitan dengan jumlah umur dan pendidikan indivdu, artinya, pendidikan yang tinggi disertai dengan pengalaman hidup yang luas seiring dengan umur yang bertambah tua.

5) Sosial Ekonomi, dimaknai bahwa tingkatan seseorang untuk memenuhi kebutuhan hidup akan disesuaikan dengan jumlah penghasilan yang ada, sehingga mengharapkan pengetahuan yang dimiliki harus dipergunakan semaksimal mungkin, hal ini sesuai pula dalam mencari bantuan ke fasilitas pelayanan kesehatan yang ada, maka akan disesuaikan dengan pendapatan keluarga. Faktor lain yang juga mendukung adalah informasi (Notoatmodjo, 2007).

Hasil penelitian didukung oleh teori yang dikemukakan oleh Atkinson dan Shiifrin dalam Satrock (2008) menyatakan bahwa semakin lama informasi dipertahankan dalam memori jangka pendek dengan bantuan pengulangan, semakin besar kemungkinannya untuk masuk ke memori jangka panjang, sehingga relative menjadi lebih permanen. Pengetahuan akan disimpan lama dalam memori jika dilakukan pengulangan dengan mengingat kembali pada saat dibutuhkan.

Pendidikan kesehatan sangat penting untuk menunjang program-program kesehatan yang lain. Pendidikan merupakan 'behavioral investment' jangka panjang. artinya pendidikan kesehatan baru dapat dilihat beberapa tahun kemudian. Dalam waktu yang pendek (immediate impact) pendidikan kesehatan hanya menghasilkan 
perubahan atau peningkatan pengetahuan masyarakat. Pengetahuan kesehatan akan berpengaruh pada perilaku sebagai hasil jangka menengah (intermediate impact) dari pendidikan kesehatan.

Selanjutnya akan berpengaruh pada peningkatan indikator kesehatan masyarakat sebagai keluaran (outcome) pendidikan kesehatan. Pendidikan kesehatan bukan hanya pelajaran di kelas, tetapi merupakan kumpulan pengalaman dimana saja dan kapan saja sepanjang klien dapat memengaruhi pengetahuan sikap dan kebiasaan. (Suliha, 2002) terdapat pula hubungan antara pengetahuan, pelatihan dan ketersediaan sarana (Sujianto, 2014). Sehingga kegiatan pelatihan sebagai salah satu upaya peningkatan kualitas pelayanan kesehatan sangat diperlukan.

Penelitian ini masih mempunyai berbagai keterbatasan yakni jumlah informan yang juga sebagai responden belum mewakili seluruh profesi yang bekerja di Puskesmas lokasi penelitian, sehingga hasilnya belum mampu direpresentasikan sebagai hasil pada tingkat Puskesmas di Kabupaten Jeneponto.

\section{KESIMPULAN}

Pelaksanaan pelatihan kolaborasi lintas profesi telah terlaksana dengan proses yang baik. Walaupun pada akhir kegiatan uji coba modul diperoleh hasil bahwa pada kegiatan uji coba modul dalam kegiatan pelatihan tersebut menunjukkan bahwa tidak terjadi perubahan pengetahuan tentang gizi buruk namun terjadi perubahan pengetahuan tentang kolaborasi lintas profesi sebagai bagian utama dari modul.

\section{DAFTAR PUSTAKA}

Alfridsyah A., Ichsan I., dan Miko A. (2013). Perbedaan Penggunaan Standar Baru Antropometri WHO-2006 terhadap Peningkatan Pengetahuan dan Penilaian Status Gizi pada Tenaga Gizi Pelaksana di Kota Banda Aceh Tahun 2009. Buletin Penelitian Sistem Kesehatan. 16 (2 Apr).

Amiruddin R. (2007). Anemia Defisiensi Zat Besi pada Ibu Hamil di Indonesia. Jurnal Medika Unhas.

Black et al. (2013). Maternal and Child Undernutrition and Overweight in Low-Income and Middle-Income Countries. The lancet. 382 (9890); 427-451.

Borst J. Inter-professional Collaboration: An Introduction. Tartalom/Table of contents. 2011:32.

Dasar RK. RISKESDAS. (2013). Badan Penelitian dan Pengembangan Badan Kesehatan Kementerian Republik Indonesia.

Departemen Kesehatan Jeneponto. (2015). Laporan Pelaksanaan Surveilans Gizi tingkat Kabupaten Jeneponto. 
Departemen Kesehatan Republik Indonesia. (2001). Modul Pelatihan Metode dan Teknologi Diklat (METEK). Pusat Pendidikan dan Latihan Pegawai Depkes RI, Jakarta. 9-11.

Ellis et.al. (2007). Effect of Pharmacy Practice Residency Training on Residents' Knowledge of and Interest in Clinical Research. American Journal of Health-System Pharmacy. 64(19).

Febria C., Masrul M dan Chundrayetti E. (2018). Hubungan Kadar Kalsium Dalam ASI, PASI Dan MPASI dari Asupan Bayi dengan Panjang Badan Bayi Usia 6-12 Bulan di Wilayah Kerja Puskesmas Lubuk Buaya Padang 2017. Jurnal Kesehatan Andalas. 6(3): 662-667.

Green BN and Johnson CD. (2015). Inter-Professional Collaboration in Research, Education, And Clinical Practice: Working Together for a Better Future. Journal of Chiropractic Education. 29(1): 1-10.

Indonesia KKR. (2015) Rencana Strategis Kementerian Kesehatan tahun 2015-2019.

Bainbridge et. al. (2010). Competencies for Inter-Professional Collaboration. Journal of Physical Therapy Education. 24(1); 6.

Notoatmodjo S. (2007). Kesehatan Masyarakat. Ilmu dan Seni. Rineka Cipta. Jakarta.

Notoatmodjo S. (2007). Pendidikan dan Prilaku Kesehatan. Jakarta: Rineka Cipta.

Palutturi S. (2007). Determinan Kinerja Bidan di Puskesmas Tahun 2006. Jurnal Manajemen Pelayanan Kesehatan. 10(04).

Paridah C, A dan Thaha, R. (2014). The Role of the Center for Prenatal and Postnatal Health Care and Information Cadres in Integrated Care for Preconception Womenin the Pattingalloang Community Health Center Area. JURNAL MKMI, 102109.

Posthumus et al. (2013). Bridging between Professionals in Perinatal Care : towards Shared Care in the Netherlands. Maternal and Child Health Journal. 17(10); 1981-1989.

Purwanto MN. (1990). Psikologi pendidikan. Remaja Rosdakarya.

Renyoet BS., Hadju V dan Rochimiwati S. (2012). Hubungan Pola Asuh Dengan Kejadian Stunting Anak Usia 6-23 Bulan di Wilayah Pesisir Kecamatan Tallo Kota Makassar. Jurnal Nutrient Science (PA-NSC), 1-13.

Sakti RE., Hadju V dan Rochimiwati SN. (2013). Hubungan Pola Pemberian MP-ASI dengan Status Gizi Anak Usia 6-23 Bulan di Wilayah Pesisir Kecamatan Tallo Kota Makassar Tahun 2013. Jurnal MKMI K.

Saleh PA., Amir MY dan Palutturi S. (2012). Hubungan Faktor Sosial dan Psikologis 
Dengan Pemanfaatan Pelayanan Kesehatan di RS Bhayangkara Makassar. Jurnal Penelitian Administrasi dan Kebijakan Kesehatan FKM Universitas Hasanuddin.

Rodriguez et. al. (2008). Outcomes of Inter-professional Collaboration for Hospitalized Cancer Patients. Cancer nursing. 31(2); 18-27.

Seif NY and Aziz MA. (2000) Effect of Breast Self-Examination Training Program on Knowledge, Attitude and Practice of a Group of Working Women. J Egypt Natl Canc Inst. 12(2); 105-115.

Sujianto U .(2014). Kepatuhan Perawat dalam penerapan kewaspadaan universal di Rumah sakit dokter Kariadi Semarang Tahun 2013. Paper presented at: Prosising seminar nasional \& Internasional .

Suliha U. (2002). Pendidikan Kesehatan dalam Keperawatan. Jakarta: Penerbit Buku Kedokteran EGC.

Sul-Sel DKp. (2015). Profil kesehatan Sulawesi Selatan.

Sumarni S. (2015) Peran Sarjana Kesehatan Masyarakat dalam Gerakan Penyelamatan 1000 HPK untuk Menurunkan Stunting dan Angka Kematian Ibu. Seminar E Saresehan Nasional Kesehatan Masyarakat. pp.20-30.

Susanty dkk. (2012). Hubungan pola pemberian ASI dan MP-ASI dengan gizi buruk pada anak 6-24 bulan di Kelurahan Pannampu Makassar. Media Gizi Masyarakat Indonesia. 1(2); 97-103.

Syam dkk. (2016). Micronutrients and growth of children; a literature review. International Journal of Medical Science and Public Health. 5(10): 1981-1987.

Unicef. (2012). Ringkasan kajian kesehatan ibu dan anak.

World Health Organization. (2010). Framework for Action on Inter-professional Education \& Collaborative Practice. 64. 